\title{
Organic Compounds Generated in Bioethanol Production from Agave Bagasse
}

Jorge A. Mejía-Barajas ${ }^{a}$, Melchor Arellano-Plazab ${ }^{b}$ Belem Vargas-Ochoaa, Rafael Salgado-Garcigliaa, Jesús Campos-García ${ }^{a}$ Alfredo Saavedra-Molina ${ }^{{ }^{*}}$

aUniversidad Michoacana de San Nicolás de Hidalgo. Instituto de Investigaciones Químico-Biológicas.

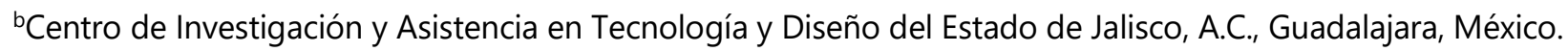
jorge.arturo17@hotmail.com,marellano@ciatej.mx, belem2501@hotmail.com, rsalgadogarciglia@gmail.com, jcgarcia@umich.mx, saavedra@umich.mx

\begin{abstract}
In bioethanol production through lignocellulosic residues fermentations are generated by-products such as organic compounds (OCs). The organic compounds (OCs) had been well studied in wine and beer industry, but little is known about their presence in bioethanol industry, even when these affect yeasts physiologic state, and are considered as economically desirable in the chemical industry. In this work was evaluated the production of OCS in bioethanol production processes through separate hydrolysis and fermentation (SHF) and simultaneous saccharification and fermentation (SSF) of different agave bagasse residue (ABR). Fermentations were carried out by the Kluyveromyces marxianus SLP1, K. marxianus OFF1 and Saccharomyces cerevisiae Ethanol Red yeasts strains. The main OCs detected were ethyl acetate, methanol, 1-propanol, isobutanol, butanol, isoamyl-alcohol, ethyl-lactate, furfuryl-alcohol, phenyl-acetate, and 2-phenyl ethanol. A higher number of OCs was found in the SSF process when were used the $K$. marxianus OFF1 and SLP1 yeasts. This study provides better knowledge of the kind and concentrations of OCs produced by fermentation of the lignocellulosic $A B R$, which allow propose bioethanol by-products as potential source of economically desirable compounds.
\end{abstract}

Indexing Terms/Keywords: Agave Bagasse; Bioethanol; By-Products; Fermentation; Organic Compounds

Academic Discipline And Sub-Disciplines: Biotechnology And Fermentation

Subject Classification: Biotechnology And Microbiology

Type (Method/Approach) :Experimental

Language: English

Date of Submission: 2018-04-11

Date of Acceptance: 2018-04-20

Date of Publication: 2018-04-30

ISSN: 2348-6201

Volume: 07 Issue: 01

Journal: Journal of Advances in Biotechnology

Website: https://cirworld.com

This work is licensed under a Creative Commons Attribution 4.0 International License. 
ISSN: 2348-6201

Volume: 07 Issue: 01

Journal of Advances in Biotechnology

\section{INTRODUCTION}

Yeasts are used to produce chemicals, pharmaceuticals, and other products such as bioethanol [1-4]. Bioethanol production through lignocellulosic wastes is considered a promising process [5]. The agave bagasse residue $(A B R)$ is a lignocellulosic waste with potential to bioethanol production $[6,7,8$, 9]; however low have been described about other organic compounds (OCs) produced in the fermentation process of that lignocellulosic residue. On the one hand, the OCs are toxic for sugar yeast fermentation rendering in consequence decreased ethanol yield $[10,11]$; but on the other hand, the OCs have multiple industrial applications such as food additives, pharmaceutical, and cosmetic excipients [4]. In yeast fermentation OCs like esters, aldehydes, ketones, carbonyls, furans, and terpenes are produces [4]. The OCs production is affected by $\mathrm{pH}$, temperature, carbon source, and yeast strain $[12,13,14]$. The Kluyveromyces marxianus genus has high potential for industrial production of OCs as volatiles compounds [11], as well as fast growth rate [15], and GRAS status.

The aim of this work was determinate the OCs obtained by the fermentation of hydrolyzes $A B R$, utilizing variables of process such as separate hydrolysis fermentation (SHF) and simultaneous saccharification and fermentation (SSF) stages, using the native yeast strains of $K$. marxianus SLP1 and OFF1 and comparing with the industrially-utilized yeast S. cerevisiae (Ethanol Red). To our knowledge, this is the first work in report the OCs produced in the fermentation of the lignocellulosic ABR. According with our results, the ABR bioethanol process could be considered as a potential way for produces economically desirable OCs.

\section{MATERIAL AND METHODS}

\section{Yeast strains}

Yeast strains were obtained from the culture collection of the CIATEJ (Centro de Investigación y Asistencia en Tecnología y Diseño del Estado de Jalisco, México) [16] and from the ATCC (American Type Culture Collection, Rockville, MD, USA). The K. marxianus yeasts strains (SLP1 and OFF1) were isolated at handcraft mezcal distilleries in the Mexican State of San Luis Potosi and Guerrero, respectively. The Ethanol Red yeast was acquired from the ATCC.

\section{Agave bagasse residue and saccharification process}

The agave bagasse residues (ABR) classified as masonry oven, autoclave and diffuser were obtained from the distilleries "Casa de Piedra", "Gonzalez-Gonzalez", and "La Madrileña", respectively. The three distilleries are located in Jalisco, Mexico. The tequila industries have different pine agave treatment as is mentioned by CedeñoCruz [17], and Casas [18]. The ABR were submitted to thermo-acid treatment showing higher sugar release under conditions previously determinate (Table 1). Enzymatic hydrolysis was done utilizing the commercial cellulases complexes $\mathrm{CTec2}$, HTec2, and Rapidase (Novo enzymes) at $1.5 \mathrm{~g}$ of enzyme/g ABR (dry weight).

Table 1. Conditions for the agave bagasse residue thermo-acid treatment

\begin{tabular}{|c|c|c|c|}
\hline$A B R$ & Autoclave & Masonry oven & Diffuser \\
\hline $\mathrm{H}_{2} \mathrm{SO}_{4}(\%)$ & 3 & 1 & 1 \\
\hline Temperature $\left({ }^{\circ} \mathrm{C}\right)$ & 110 & 130 & 110 \\
\hline Time (min) & 40 & 30 & 10 \\
\hline
\end{tabular}


ISSN: 2348-6201

Volume: 07 Issue: 01

Journal of Advances in Biotechnology

ABR, Agave Bagasse Residue.

\section{Fermentation processes}

The enzymatic hydrolysates ABR were fermented through separate hydrolysis and fermentation (SHF) or simultaneous saccharification and fermentation (SSF), using the $K$. marxianus yeasts SLP1 and OFF1, or the $S$. cerevisiae Ethanol Red. $1 \times 10^{7} \mathrm{cells} / \mathrm{ml}$ suspensions was added with the enzymes mix or after $48 \mathrm{~h}$ of enzymatic hydrolysates of $A B R$, to SSF or SHF, respectively. The fermentations were done at $40^{\circ} \mathrm{C}$ and $100 \mathrm{rpm}$. Samples were taken at $24 \mathrm{~h}$ and $48 \mathrm{~h}$ after yeast inoculation. The OCs were detected by gas chromatography, as mentioned below.

\section{Analysis of organic compounds}

The OCs determination was carried out as described previously [19]. Briefly, after $48 \mathrm{~h}$ of fermentation OCs were quantified using a Hewlett-Packard 6890 gas chromatograph (Palo Alto, CA, USA) with flame ionization detector (FID) equipped with an HP-Innowax PEG column $(60 \mathrm{~m}, 0.320 \mathrm{~mm})$. The initial column temperature was $45^{\circ} \mathrm{C}$, then ramped at $10^{\circ} \mathrm{C} / \mathrm{min}$ to $160^{\circ} \mathrm{C}$, followed by a $20^{\circ} \mathrm{C} / \mathrm{min}$ ramp to $220^{\circ} \mathrm{C}$, maintained during $4 \mathrm{~min}$. Injector and detector temperatures were maintained at $250^{\circ} \mathrm{C}$. The injection system consisted in a head-space (HewlettPackard 7694E). The preparation program and injection simple started with vial temperature at $80^{\circ} \mathrm{C}$, loop temperature at $110^{\circ} \mathrm{C}$, and transfer line temperature of $115^{\circ} \mathrm{C}$. The cycle time of head space and gas chromatograph was of $40 \mathrm{~min}$, with vial equilibrium time of $5 \mathrm{~min}$, pressurization time $0.2 \mathrm{~min}$, filling loop time $0.2 \mathrm{~min}$, loop equilibrium time $0.5 \mathrm{~min}$, injection time and agitation time of $1 \mathrm{~min}$. The OCs measured in this study were ethyl-acetate, methanol, ethyl-butyrate, 1-propanol, isobutanol, isoamyl-acetate, butanol, isoamyl-alcohol, ethyl-hexanoate, ethyl-lactate, ethyl-octanoate, ethyl-decanoate, furfuryl-alcohol, phenyl-acetate, and 2phenylethanol. As external standard were used compounds purchased from Sigma-Aldrich.

\section{Yeasts cell growth}

Cell number was determined by cell counting in Neubauer chamber by a sample taken at $24 \mathrm{~h}$ and $48 \mathrm{~h}$ after yeast fermentation. The counting was done according to Strober [20].

\section{RESULTS}

\section{Total organic compounds produced}

The $K$. marxianus yeast OFF1 showed more number of higher total organic compounds (TOCs) concentrations than the other yeasts. The TOCs concentrations were from 11 to $374 \mathrm{mg} / \mathrm{L}$. SLP1 yeast obtained the highest concentration generated (Table 2). Although the higher TOCs concentrations were through SHF (Table 2), a higher number of OCs was generated in the SSF process. The compounds ethyl acetate, 1-propanol, isobutanol, butanol and isoamyl-alcohol were detected in the SSF of autoclave ABR, while in the SHF of the same ABR were no detected. In general was detected a lesser number of OCs as well as TOCs concentrations, in the fermentation of masonry oven $A B R$, compared with the detected in fermentations of autoclave and diffuser ABR (Table 2). The phenyl-acetate and furfuryl-alcohol were not detected in the fermentations of diffuser $A B R$ while in the rest of the samples has variable concentrations around 15 and $50 \mathrm{mg} / \mathrm{L}$, respectively. The ethyl acetate concentration was the most influenced by the ABR kind; when was used the autoclave ABR this compound was detected only in the SSF process; with the masonry oven ABR the presence of the ethyl-acetate was variable, while with the diffuser $A B R$ this compound was present in all the samples. Others OCs presents in all the conditions were the methanol and 2-phenylethanol. 
Table 2. Total organic compounds (TOCs) in separate hydrolysis and fermentation (SHF) or simultaneous saccharification and fermentation (SSF) of the agave bagasse residue (ABR).

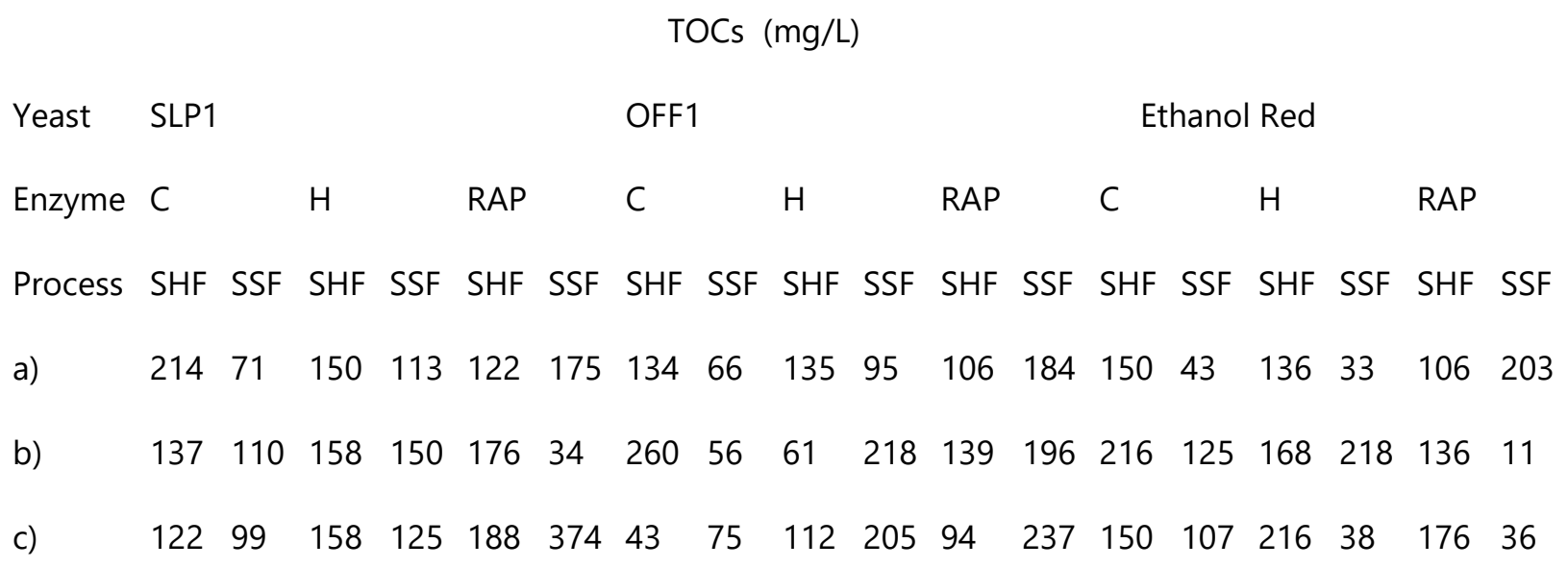

ABR hydrolysates from autoclave (a), masonry oven (b) and diffuser (c). The fermentations were carried out in shake flasks at $40^{\circ} \mathrm{C}$ and $100 \mathrm{rpm}$. Enzyme: C (CTec2), H (HTec2) and RAP (Rapidase). Samples were taken at $48 \mathrm{~h}$ of fermentations processes.

\section{Higher concentrations of the OCs detected}

Were detected ten OCs with concentrations lesser than $300 \mathrm{mg} / \mathrm{L}$ (Table 3). The OC with the higher concentration was ethyl acetate $(249 \mathrm{mg} / \mathrm{L})$, followed by the 2 -phenylethanol $(75.31 \mathrm{mg} / \mathrm{L})$. The $K$. marxianus yeasts SLP1 and OFF1 produced a higher number of OCs and concentrations of seven of the ten compounds detected. The methanol, butanol and ethyl-lactate were the OCs produced in higher concentration by the S. cerevisiae Ethanol Red yeast. While K. marxianus yeasts generated the $70 \%$ of the higher OCs concentrations, $60 \%$ were through SSF.

The compounds found in higher concentrations in SHF were methanol, ethyl-lactate, furfuryl-alcohol and 2phenylethanol. The enzymatic complex showed a significance influence respect the higher concentrations; due $60 \%$ of the higher OCs concentrations were generated from hydrolysates by the Rapidase enzyme (Table 3).

Table 3. Higher concentrations of the organic compounds (OCs) detected

$\begin{array}{llllll}\text { OCs } & \text { Concentration } & \text { Yeast } & \text { Process } & \text { ABR } & \text { Enzyme } \\ & (\mathrm{mg} / \mathrm{L}) & & & & \\ \text { Ethyl-acetate } & 249.38 & \mathrm{~S} & \mathrm{SSF} & \mathrm{D} & \mathrm{RAP} \\ \text { Methanol } & 45.97 & \text { ER } & \text { SHF } & \text { D } & \text { RAP } \\ \text { 1-propanol } & 12.56 & \text { O } & \text { SSF } & \text { A } & \text { RAP } \\ \text { Isobutanol } & 24.52 & \text { O } & \text { SSF } & \text { A } & \text { RAP }\end{array}$


ISSN: 2348-6201

Volume: 07 Issue: 01

Journal of Advances in Biotechnology

$\begin{array}{llllll}\text { Butanol } & 3.69 & \text { ER } & \text { SSF } & \text { A } & \text { RAP } \\ \text { Isoamyl-alcohol } & 34.81 & \text { O } & \text { SSF } & \text { A } & \text { RAP } \\ \text { Ethyl-lactate } & 65.17 & \text { ER } & \text { SHF } & \text { M } & \text { C } \\ \text { Furfuryl-alcohol } & 57.05 & \text { O } & \text { SHF } & \text { A } & \text { C } \\ \text { Phenyl acetate } & 17.61 & \text { S } & \text { SSF } & \text { M } & \text { C } \\ \text { 2-phenyl ethanol } & 75.31 & \text { S } & \text { SHF } & \text { M } & \text { C }\end{array}$

Yeasts: SLP1 (S), OFF1 (O) and Ethanol Red (ER). Processes: Separate hydrolysis and fermentation (SHF) and simultaneous saccharification and fermentation (SSF). Agave bagasse residue (ABR): A (autoclave); M (masonry oven); D (diffuser). Enzymatic complex: CTec2 (C) and Rapidase (RAP).

\section{Yeasts cell grown}

In eleven of the eighteen different fermentations conditions generated, the SLP1 yeast increased their cells number at $48 \mathrm{~h}$ with respect to $24 \mathrm{~h}$ of fermentation; in the seven rest conditions preserve their cells number at $48 \mathrm{~h}$. In contrast, in six conditions the $K$. marxianus OFF1 yeast showed a reduction in the cells number from $24 \mathrm{~h}$ to $48 \mathrm{~h}$ of fermentation. The industrial $\mathrm{S}$. cerevisiae yeast (Ethanol Red) showed a reduction in their cells number in three samples, preserves their cells number in ten conditions, and increased the cells number in five conditions of the eighteen generated, comparing at $48 \mathrm{~h}$ with respect $24 \mathrm{~h}$ of fermentation (Table 4)

Table. 4 Yeast cells number $\left(1 \times 10^{6}\right.$ cells $\left./ \mathrm{ml}\right)$.

$\begin{array}{ll}\text { Yeas } & \text { SLP1 } \\ t\end{array}$

Enzy

me

C

$\mathrm{H}$

RAP

M

$\mathrm{D}$

A

M

A

M

$\begin{array}{lllllllllllllllllll}\begin{array}{l}\text { Time } \\ \text { (h) }\end{array} & 24 & 48 & 24 & 48 & 24 & 48 & 24 & 48 & 24 & 48 & 24 & 48 & 24 & 48 & 24 & 48 & 24 & 48\end{array}$

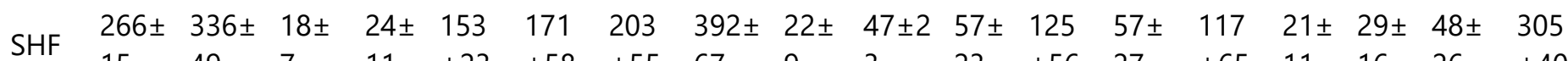
$\begin{array}{llllllllllllllllll}15 & 49 & 7 & 11 & \pm 23 & \pm 58 & \pm 55 & 67 & 9 & 3 & 23 & \pm 56 & 27 & \pm 65 & 11 & 16 & 26 & \pm 40\end{array}$

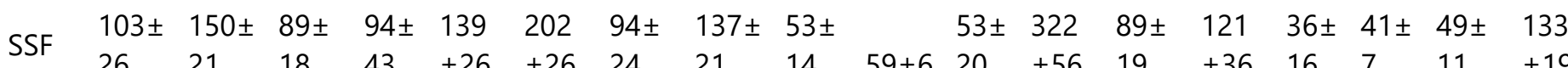
$\begin{array}{llllllllllllllllll}26 & 21 & 18 & 43 & \pm 26 & \pm 26 & 24 & 21 & 14 & 59 \pm 6 & 20 & \pm 56 & 19 & \pm 36 & 16 & 7 & 11 & \pm 19\end{array}$

Yeas

$\mathrm{t}$

OFF1

$\begin{array}{lllllllllllllllllll}\text { SHF } & 62 \pm 1 & 79 \pm 2 & 18 \pm & 59 \pm & 98 \pm & 176 & 69 \pm & 29 \pm 1 & 72 & 54 & 77 \pm & 93 \pm & 89 \pm & 89 \pm & 41 \pm 32 \pm & 62 \pm & 162\end{array}$ $\begin{array}{llllllllllllllllll}7 & 6 & 8 & 11 & 25 & \pm 35 & 28 & 1 & \pm 17 & \pm 16 & 15 & 21 & 24 & 53 & 25 & 11 & 18 & \pm 44\end{array}$ 
ISSN: 2348-6201

Volume: 07 Issue: 01

Journal of Advances in Biotechnology

$\begin{array}{lllllllllllllllllll}\text { SSF } & 75 \pm 3 & 45 \pm 2 & 141 & 57 \pm & 94 \pm & 81 \pm & 126 & 50 \pm 1 & 63 & 100 & 70 \pm & 157 & 167 & 265 & 81 \pm & 81 \pm & 70 \pm & 189 \\ & 2 & 5 & \pm 45 & 31 & 20 & 30 & \pm 35 & 7 & \pm 24 & \pm 33 & 14 & \pm 36 & \pm 38 & \pm 74 & 41 & 24 & 26 & \pm 56\end{array}$

Yeas

$\mathrm{t}$

Ethanol Red

$\mathrm{SHF}$

$\begin{array}{llllllllllllllllll}462 \pm & 227 \pm & 33 \pm & 15 \pm & 383 & 54 \pm & 54 \pm & 99 \pm 5 & 41 \pm & 52 \pm 2 & 71 \pm & 180 & 62 \pm & 236 & 22 \pm & 42 \pm & 152 & 348\end{array}$ $\begin{array}{llllllllllllllllll}80 & 80 & 10 & 5 & \pm 77 & 19 & 39 & 0 & 11 & 5 & 29 & \pm 45 & 24 & \pm 54 & 7 & 11 & \pm 40 & \pm 67\end{array}$

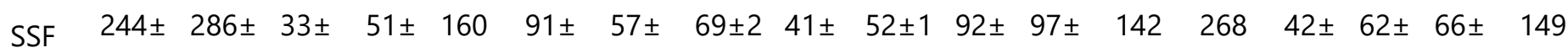

$\begin{array}{llllllllllllllllll}51 & 79 & 5 & 18 & \pm 61 & 46 & 21 & 4 & 7 & 7 & 41 & 54 & \pm 57 & \pm 75 & 12 & 11 & 30 & \pm 56\end{array}$

The cells were counted after $24 \mathrm{~h}$ and $48 \mathrm{~h}$ of separate hydrolysis and fermentation (SHF) or simultaneous saccharification and fermentation (SSF). Agave bagasse residue (ABR): A (autoclave); $M$ (masonry oven); D (diffuser). Enzymatic complex: CTec2 (C), HTec2 (H) and Rapidase (RAP).

\section{DISCUSSION}

The utilization of lignocellulosic wastes as substrate in bioprocesses has increased in recent years due their renewable capacity, low-priced, and abundance [21,22]. In Mexico the lignocellulosic agave bagasse is produced in tequila industry as waste with a rate of 360 thousand of dry tons [17, 23]. The agave bagasse residue (ABR) had been reported as a promising lignocellulosic biomass for production of fermentable sugars [7], and bioethanol $[6,7,8,9,24]$; however, there is not information about bioethanol by-products from ABR.

Organic compounds (OCs) are produced in the secondary yeast metabolism and can be considered as bioethanol contaminants [25], which could be yeast toxic [10, 11, 26]; moreover, these compounds has potential industrial use with high commercial interest in the food, cosmetics, detergent and pharmaceutical industries [4]. K. marxianus yeasts are some of the best organic volatiles compounds (OVCs) yeasts producer [11], and theirs use to produced these compounds through cassava bagasse fermentation is a feasibility process [27]. As well as cassava bagasse, sugar cane bagasse has been used for OVCs production [28, 29], without considered at the moment the ABR.

In this work we studied the OCs produced as bioethanol by-product from ABR fermentation using two $K$. marxianus yeasts (SLP1 and OFF1) and the industrially utilized yeast $S$. cerevisiae (Ethanol Red). Ethanol production from lignocellulosic biomass like ABR includes four main steps: pretreatment, saccharification, fermentation and distillation [30]. This study was focus in the OCs present in the fermentation step, using the $A B R$ after theirs saccharification.

In our results were detected a lesser number of OCs than the reported López-Alvarez et al. [31] when used the $K$. marxianus yeast UMPe- 1 to ferment agave must; this effect is due the agave must has higher sugar concentration than the ABR [6], and a major sugar concentration can result in higher OCs concentration [32].

Cedeño-Cruz [17], and Casas [18] explained that in tequila industries autoclave, masonry oven or diffuser could process the agave pines. We observed that agave pine process could affect the TOCs concentrations, as well as the kind of OCs produced (Table 2). This effect could be results of the kind and concentration of sugars in the ABR after agave pine processed.

The compound ethyl acetate is considered a solvent with many industrial applications. $K$. marxianus yeasts are some of the most potential yeasts for the production of ethyl acetate in an industrial scale [33]. In this work the higher ethyl acetate concentration was $249 \mathrm{mg} / \mathrm{L}$, concentration lesser than the reported as $K$. marxianus 
ISSN: 2348-6201

Volume: 07 Issue: 01

Journal of Advances in Biotechnology

growth inhibitor (17 $\mathrm{g} / \mathrm{L})$ [10]; moreover copper limitation can increase ethyl-acetate synthesis in Kluyveromyces yeasts [34].

Yeasts are considered the most promising producers of 2-phenylethanol. The 2-phenylethanol is one of the more commercially OVCs due to their rose-like aroma [35], and in our results (Table 3) was the second more abundant compound. Although Kluyveromyces strains are considered as good producers of this compound [36], their resistance to this compound is lower than that of S. cerevisiae [37]. A concentration of $2 \mathrm{~g} / \mathrm{L}$ of 2 phenylethanol is toxic to $K$. marxianus yeasts, and ethanol generates a synergistic interaction amplifying its cytotoxicity [38]. The higher 2-phenyl ethanol concentration produced in this work was of $75 \mathrm{mg} / \mathrm{L}$, which is similar than the produced using molasses-based medium by the $K$. marxianus CBS $600(89 \mathrm{mg} / \mathrm{L})$ reported by Etschmann et al. [39]. Compound levels could increase through addition of exogenous L-phenylalanine [37, 40], or through solid-phase in situ product removal [41].

The higher alcohols detected in the ABR fermentations showed concentrations from 3.69 to $34.81 \mathrm{mg} / \mathrm{L}$. The 1 -propanol and isobutanol were detected in agave Tequilana fermentation with the same $K$. marxianus yeasts used in our work [42]. While the isobutanol can be used for production of bio-based product packaging [43], the butanol is considered a fuel additive [44]. The butanol concentration (20 mg/L) detected in the "Tequila Blanco" beverage obtained using the $K$. marxianus UMPe-1 [31], was higher than the detected using the ABR $(3.69 \mathrm{mg} / \mathrm{L})$. With the exception of butanol, in this work the $K$. marxianus yeasts showed major production of higher alcohols than the $S$. cerevisiae yeast, results that are in agreement with the reported by López-Alvarez et al. [31]. Although amino acids availability influences higher alcohols production, the uptake and assimilation of these substrates determines the final concentration [4]. According with our results the uptake and amino acid assimilation could be better in the $K$. marxianus yeasts (SLP1 and OFF1) than the $S$. cerevisiae yeast (Ethanol Red).

The ethyl-lactate that is used as solvent and "building block" to produce degradable plastic polymers [45] was not found in the fermentations by the SLP1 yeast, while the Ethanol Red yeast produced $2 \mathrm{mg} / \mathrm{L}$, and the OFF1 yeast $60 \mathrm{mg} / \mathrm{L}$. This last concentration is similar than the reported by Arellano et al. [42], during mezcal fermentation using the same yeast strain (OFF1). When López-Alvarez et al. [31] compared the production of this compound between the $K$. marxianus UMPe- 1 and the $S$. cerevisiae baker's Pan 1 , the $S$. cerevisiae yeast produced seven times more than the $K$. marxianus yeast, result that is in disagreement with the results in this work, due the production by the K. marxianus OFF1 was higher than the produced by the S. cerevisiae yeast Ethanol Red. Due the last, we suggested that the production of ethyl-lactate could depend in great of every yeast strain, even in yeasts of the same genus.

While the $K$. marxianus SLP1 yeast showed more adaptability avoiding reduces their cell number at $48 \mathrm{~h}$ of fermentation, the yeast strain with the lesser adaptability was the OFF1, reducing their cell number main in the SHF, process where were detected the higher concentrations of furfuryl-alcohol (Table 4). Although the concentrations of OCs detected were lesser than their yeast toxic values, the OCs mix could exert a synergic toxic effect with other stress conditions as $\mathrm{pH}$ and temperature $[38,46]$. Yeast robustness and physiological fitness is of high importance to efficient fermentation process [4]. A promising approach in yeasts OCs adaptation could be the study of the membrane fatty acids, due the membrane is one of the first OCs targets [47].

In this work we found that ABR fermentation could be a source of OCs, moreover, immobilized cells of $S$. cerevisiae produced higher amount of OCs than cells in suspension [48], and Rossi et al. [49] got higher overall concentration of VOCs when mixed different carbon and nitrogen sources, therefore, OCs production as bioethanol by-products from ABR could be improved through the uses of similar techniques. In addition, continuously OCs removing from $A B R$ fermentation is an option to reduce their toxic effect and increases bioethanol production. 
ISSN: 2348-6201

Volume: 07 Issue: 01

Journal of Advances in Biotechnology

According with the results of this work, $K$. marxianus yeasts in bioethanol production from ABR generated acetate esters and higher alcohols with higher concentrations through SSF. Although bioethanol production from $A B R$ is as potential source of by-compounds economically desirable, improve their production should be considered.

\section{Conflicts of Interest}

The authors declare no conflicts of interest in this work.

\section{Funding Statement}

Jorge Mejía-Barajas was CONACYT Scholarship. The research was partially funded by CONACYT (169093) and CIC. UMSNH (2.16).

\section{ACKNOWLEDGMENTS}

The authors appreciate the partial economic support from the grants of CONACYT (169093) and Coordinación de Investigación Científica. UMSNH (2.16).

\section{REFERENCES}

1. Wang, Z.X., Zhuge, J., Fang, H., Prior, B.A. Glycerol production by microbial fermentation: a review. Biotechnology Advances, 2001. 19(3): p. 201-223.

2. Johnson, E.A. Biotechnology of non-Saccharomyces yeasts-the ascomycetes. Applied Microbiology and Biotechnology, 2013. 97: p. 503-517.

3. Liu, L., Redden, H., Alper, H.S. Frontiers of yeast metabolic engineering: diversifying beyond ethanol and Saccharomyces. Current Opinion in Biotechnology, 2013. 24(6): p. 1023-1030.

4. Tesfaw, A., Assefa, F. Current Trends in Bioethanol Production by Saccharomyces cerevisiae: Substrate, Inhibitor Reduction, Growth Variables, Coculture, and Immobilization. International Scholarly Research Notices, 2014. 2014: Article ID 532852. P. 1-11.

5. Hernández-Salas, J.M., Villa-Ramírez, M.S., Veloz-Rendón, J.S., Rivera-Hernández, K.N., González-César, R.A., Plascencia-Espinosa, M.A. Comparative hydrolysis and fermentation of sugarcane and agave bagasse, Bioresource Technology, 2009. 100: p. 1238-1245.

6. Saucedo-Luna, J., Castro-Montoya, A., Martinez-Pacheco, M., Sosa-Aguirre, C., Campos-Garcia, J. Efficient chemical and enzymatic saccharification of the lignocellulosic residue from Agave tequilana bagasse to produce ethanol by Pichia caribbica, Journal of Industrial Microbiology \& Biotechnology, 2011. 38: p. 725732.

7. Pérez-Pimienta, J.A., Lopez-Ortega, M.G., Varanasi, P., Stavila, V., Cheng, G., Singh, S. Comparison of the impact of ionic liquid pretreatment on recalcitrance of agave bagasse and switch grass. Bioresource Technology, 2013. 127: p. 18-24.

8. Caspeta, L., Caro-Bermúdez, M.A., Ponce-Noyola, T., Martinez, A. Enzymatic hydrolysis at high-solids loadings for the conversion of agave bagasse to fuel ethanol. Applied Energy, 2014. 113: p. 277-286. 
ISSN: 2348-6201

Volume: 07 Issue: 01

Journal of Advances in Biotechnology

9. Urit, T., Li, M., Bley, T., Loser, C. Growth of Kluyveromyces marxianus and formation of ethyl acetate depending on temperature. Applied Microbiology and Biotechnology, 2013. 97: p 10359-10371.

10. Morrissey, J.P., Etschmann, M., Schrader, J., Billerbeck, G.M. Cell factory applications of the yeast Kluyveromyces marxianus for the biotechnological production of natural flavour and fragrances molecules. Yeast, 2015. 32: p. 3-16.

11.Molina, A.M., Guadalupe, V., Varela, C., Swiegers, J.H., Pretorius, I.S., Agosin, E. Differential synthesis of fermentative aroma compounds of two related commercial wine yeast strains. Food Chemistry, 2009. 117: p. 189-195.

12. Olaniran, A., Maharaj, Y., Pillay, B. Effects of fermentation temperature on the composition of beer volatile compounds, organoleptic quality and spent yeast density. Electronic Journal of Biotechnology, 2011. 2011: p. 1-10.

13. Gethins, L., Güneşer, O., Demirkol, A., Rea, M.C., Stanton, C., Ross, R.P., Yuceer, Y., Morrissey, J.P. Influence Of Carbon And Nitrogen Source On Production Of Volatile Fragrance And Flavour Metabolites By The Yeast Kluyveromyces Marxianus. Yeast, 2015. 32: p. 67-76.

14. Groeneveld, P., Stouthamer, A.H., Westerhoff, H.V. Super life-how and why 'cell selection' leads to the fastest-growing eukaryote. FEBS Journal, 2009. 276: p. 254-270.

15. Gschaedler, A., Ramírez, J., Díaz, D., Herrera, E., Arrizón, J., Pinal, L., Arellano, M. Fermentación. En: Ciencia y Tecnología del Tequila Avances y Perspectivas. CIATEJ, Guadalajara, Jalisco, México, 2004. 61-120.

16. Cedeño-Cruz, M. Tequila production from agave; historical influences and contemporary processes. The alcohol textbook. 4th ed. Nottingham University Press, 2003. p. 223-245.

17.Flores, J.A., Gschaedler, A., Amaya-Delgado, L., Herrera-López, E.J., Arellano, M., Arrizon, J. Simultaneous saccharification and fermentation of Agave tequilana fructans by Kluyveromyces marxianus yeasts for bioethanol and tequila production. Bioresource Technology, 2013. 146: p. 267-273.

18. Strober, W. Trypan blue exclusion test of cell viability. Current Protocols in Immunology, 2001. 21: p. A.3B.1A.3B.2.

19. Girio, F.M., Fonseca, C., Carvalheiro, F., Duarte, L.C., Marques, S., Bogel-Lukasik, R. Hemicelluloses for fuel ethanol: A review. Bioresource Technology, 2010. 13: p. 4775-4800.

20.Isikgora, F.H., Becer, C.R. Lignocellulosic biomass: a sustainable platform for the production of bio-based chemicals and polymers. Polymer Chemistry, 2015. 6: p. 4497-4559.

21. Tequila Regulatory Council. Total production of tequila. 2010. Retrieved from. $<$ http://www.crt.org.mx/EstadisticasCRTweb/>.

22. Barrera, I., Amezcua-Allieri, M.A., Estupiñan, L., Martínez, T., Aburto, J. Technical and economical evaluation of bioethanol production from lignocellulosic residues in Mexico: Case of sugarcane and blue agave bagasses. Chemical Engineering Research and Design, 2016. 107: p. 91-101. 
ISSN: 2348-6201

Volume: 07 Issue: 01

Journal of Advances in Biotechnology

23. Styarini, D., Aristiawan, Y., Aulia, F., Abimanyu, H., Sudiyani, Y. Determination of organic impurities in lignocellulosic bioethanol product by GC-FID. Energy Procedia, 2013. 32: p. 153-159.

24.Rossouw, D., Naes, T., Bauer, F.F. Linking gene regulation and the exo-metabolome: A comparative transcriptomics approach to identify genes that impact on the production of volatile aroma compounds in yeast. BMC Genomics, 2009. 9: p. 530-548.

25. Carlquist, M., Gibson, B., Yüceer, Y., Paraskevopoulou, A., Sandell, M., Angelov, A.l., Gotcheva, V., Angelov, A.D., Etschmann, M., Billerbechk, G.M., Lidén, G. Process Engineering For Bioflavour Production With Metabolically Active Yeasts - A Mini-Review. Yeast, 2015. 32: p. 123-143.

26. Medeiros, A.B.P., Pandey, A., Christen, P., Freitas, R.J.S., Fontoura, P.S.G., Soccol, C.R. Aroma compounds produced by Kluyveromyces marxianus in solid state fermentation on a packed bed column bioreactor. World Journal of Microbiology \& Biotechnology, 2001. 17: p. 767-771.

27. Bramorski, A., Christen, P., Ramirez, M., Soccol, C.R., Revah, S. Production of volatile compounds by the fungus Rhizopus oryzae during solid state cultivation on tropical agroindustrial substrates. Biotechnology Letters, 1998. 20: p. 359-362.

28.Soares, M., Christen, P., Pandey, A., Soccol, C.R. Fruity flavor production by Ceratocystis fimbriata grown on coffee husk in solid-state fermentation. Process Biochemistry, 2000. 35: p. 857-861.

29.Tomas-Pejo, E., Garcia-Aparicio, M., Negro, M.J., Oliva, J.M., Ballesteros, M. Effect of different cellulase dosages on cell viability and ethanol production by Kluyveromyces marxianus in SSF processes. Bioresource Technology, 2009. 100: p. 890-895.

30.López-Alvarez, A., Díaz-Pérez, A.L., Sosa-Aguirre, C., Macías-Rodríguez, L., Campos-García, J. Ethanol yield and volatile compound content in fermentation of agave must by Kluyveromyces marxianus UMPE- 1 comparing with Saccharomyces cerevisiae baker's yeast used in tequila production. Journal of Bioscience and Bioeng ineering, 2012. 113(5): p. 614-618.

31.Ali, K., Maltese, F., Choi, Y.H., Verpoorte, R. Metabolic constituents of grapevine and grape-derived products. Phytochemistry Reviews, 2010. 9: p. 357-378.

32. Casas, R. Between traditions and modernity: Technological strategies at three tequila firms. Techhnology in Society, 2006. 28: p. 407-419.

33. Löser, C., Urit, T., Keil, P., Bley, T. Perspectives for the biotechnological production of ethyl acetate by yeasts. Applied Microbiology and Biotechnology, 2014. 98: p. 5397-5415.

34. Löser C, Urit T, Keil P, Bley T (2015) Studies on the mechanism of synthesis of ethyl acetate in Kluyveromyces marxianus DSM 5422. Applied Microbiology and Biotechnology, 2015. 99(3): p. 1131-1144.

35. Wittmann, C., Hans, M., Bluemke, W. Metabolic physiology of aroma producing Kluyveromyces marxianus. Yeast, 2002. 19(15): p. 1351-1363.

36. Kim, B., Cho, B.R., Hahm, J.S. Metabolic engineering of Saccharomyces cerevisiae for the production of 2phenylethanol via Erlich pathway. Biotechnol Bioeng, New York, 2014. 111: p. 115-124. 
ISSN: 2348-6201

Volume: 07 Issue: 01

Journal of Advances in Biotechnology

37. Etschmann, M.M., Bluemke, W., Sell, D., Schrader, J. Biotechnological production of 2-phenylethanol. Applied Microbiology and Biotechnology, 2002. 59: p. 1-8.

38.Wang, H., Dong, Q., Guan, A., Meng, C., Shi, X., Guo, Y. Synergistic inhibition effect of 2-phenylethanol and ethanol on bioproduction of natural 2-phenylethanol by Saccharomyces cerevisiae and process enhancement. Journal of Bioscience and Bioengineering, 2011. 112: p. 26-31.

39. Etschmann, M.M., Sell, D., Schrader, J. Screening of yeasts for the production of the aroma compound 2phenylethanol in a molasses-based medium. Biotechnology Letters, 2003. 25: p. 531-536.

40. Etschmann, M.M., Sell, D., Schrader, J. Production of 2-phenylethanol and 2 phenylethylacetate from Lphenylalanine by coupling whole-cell biocatalysis with organophilic pervaporation. Biotechnology and Bioengineering, 2005. 92: p. 624-634.

41.Gao, F., Dauguli, J. Bioproduction of the Aroma Compound 2-Phenylethanol in a Solid-Liquid Two-Phase Partitioning Bioreactor System by Kluyveromyces marxianus. Biotechnology and Bioengineering, 2009. 104: p. 332-339.

42. Arellano M, Gschaedler A, Alcazar M (2012) Major Volatile Compounds Analysis Produced from Mezcal Fermentation Using Gas Chromatography Equipped Headspace (GC-HS) Gas Chromatography in Plant Science, Wine Technology, Toxicology and Some Specific Applications.

43.Peters, M.W., Taylor, J.D., Jenni, M., Manzer, L., Henton, D.E. Integrated process to selectively convert renewable isobutanol to P-xylene. Gevo patent US 2011087000 (A1).

44. Lee, S.Y., Park, J.H., Jang, S.H., Nielsen, L.K., Kim, J., Jung, K.S. Fermentative Butanol Production by Clostridia. Biotechnology and Bioengineering, 2008. 101: p. 209-228.

45.Zlokazov, M.V., Veselovsky, V.V. A novel polyfunctional chiral building block derived from (S)-ethyl-lactate. Application to the synthesis of the sex pheromone of the southern corn root worm (Diabrotica undecimpunctata howardi). Russian Chemical Bulletin, 2000. 49: p. 154-158.

46. Belloch, C., Orlic, S., Barrio, E., Querol, A. Fermentative stress adaptation of hybrids within the Saccharomyces sensu stricto complex. International Journal of Food Microbiology, 2008. 122: p. 188-195.

47. Mannazzu, I., Angelozzi Ł. D., Belviso, S., Budroni, M., Farris, G.A., Goffrini P., Lodi, T., Marzona, M., Bardi, L. Behaviour of Saccharomyces cerevisiae wine strains during adaptation to unfavourable conditions of fermentation on synthetic medium: cell lipid composition, membrane integrity, viability and fermentative activity. International Journal of Food Microbiology, 2008. 15: p. 84-91.

48.Lalou, S., Mantzouridou, F., Paraskevopoulou, A., Bugarski, B., Levic, S., Nedovic, V. Bioflavour production from orange peel hydrolysate using immobilized Saccharomyces cerevisiae. Applied Microbiology Biotechnology, 2013. 97: p. 9397-9407.

49. Rossi, S.C., Vandenberghe, L.P.S., Pereira, B.M.P., Gago, F.D., Rizzolo, J.A., Pandey, A., Soccol, C.R., Medeiros, A.B.P. Improving fruity aroma production by fungi in SSF using citric pulp. Food Research International, 2009. 42: p. 484-486. 
ISSN: 2348-6201

Volume: 07 Issue: 01

Journal of Advances in Biotechnology

\section{Author' biography with Photo}

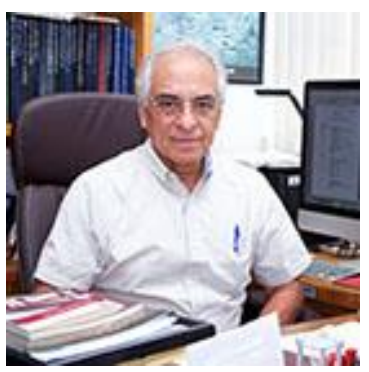

Dr. Alfredo Saavedra-Molina is Professor at the Institute of Biology Chemistry Research in the Universidad Michoacana de San Nicolás de Hidalgo, Morelia, Mich. México. Part of his research interest is related to indigenous mezcal yeasts that are under constant stress during fermentation with special focus on their adaptation systems to survive that condition. 